\title{
Imaging Findings of Ischemic Stroke Associated with COVID-19
}

\author{
COVID-19 ile İlișkili İskemik İnmenin Görüntüleme Bulguları \\ iD Nurdan Gocgun, (iD Turkan Ikizceli \\ University of Health Sciences, Istanbul Haseki Training and Research Hospital, Department of Radiology, Istanbul, Turkey.
}

\begin{abstract}
Objective: We aimed to present the relationship between ischemic stroke and COVID-19, stroke types, and imaging findings in COVID-19 with stroke.

Material and Method: From March to November 2020, COVID-19 diagnosed in patients with stroke (n=10) was included in the study retrospectively. To eliminate intracranial hemorrhage, a non-contrast computed tomography (CT) was performed for all patients. Then, magnetic resonance imaging (MRI) and Diffusion-Weighted MRI (DWI) $(n=10)$ were obtained. Magnetic resonance angiography was performed in patients whose CT angiography was contraindicated. Clinical information, stroke risk factors, and case imaging results were recorded. Stroke time, size, location (cortical, deep lacunar, and white matter), and vascular territory area were evaluated.

Results: The mean age of the 10 patients included in the study was $62 \pm 15.10$ years. All patients had an ischemic stroke. In total, 4 cases (40\%) did not have any risk factors for cerebral vascular disease. Based on DWI results, seven cases were assessed as acute strokes (70\%) and three cases as sub-acute strokes (30\%). The size of the stroke was $21.80 \pm 15.83 \mathrm{~mm}$. In 4 cases, the size was extended cortical areas. 3 cases were cortical, 5 cases had a lacunar infarction, 2 cases had cortical and lacunar infarctions. 6 cases were in the posterior cerebral artery territory and 4 cases were in the anterior territory.

Conclusion: The presentation of patients with stroke during COVID-19 therapy or after therapy might be considered the hypothesis that the virus led to a stroke, especially in cases accompanied by risk factors.
\end{abstract}

\section{ÖZET}

Amaç: Inme ile COVID-19 arasındaki ilişkiyi, inme tipleri ve görüntüleme bulguları sunmayı amaçladık. Gereç ve Yöntem: Mart-Kasım 2020 arasında, inmesi olan $(n=10)$ COVID-19 teşhisi konulan hastalar retrospektif olarak çalışmaya dahil edildi. Intrakraniyal kanamayı ortadan kaldırmak için tüm hastalara kontrastsız bilgisayarlı tomografi (BT) yapıldı. Daha sonra manyetik rezonans görüntüleme ve Difüzyon Ağırlıkl MR (DAG) elde edildi. BT anjiyografisi kontrendike olan hastalara manyetik rezonans anjiyografi yapıldı. Klinik bilgiler, inme risk faktörleri ve görüntüleme sonuçları kaydedildi. Inme süresi, boyutu, konumu (kortikal, derin laküner ve beyaz cevher) ve vasküler bölge alanı değerlendirildi.

Bulgular: Çalışmaya alınan 10 hastanın ortalama yaşı $62 \pm 15.10$ idi. Tüm hastalarda iskemik inme vardl. Toplamda 4 vakada (\%40) serebral vasküler hastallk için herhangi bir risk faktörü yoktu. DAG sonuçlarına göre yedi vaka akut inme (\%70) ve üç vaka subakut inme (\%30) olarak değerlendirildi. İnme boyutu $21.80 \pm 15.83 \mathrm{~mm}$ idi. 4 olguda geniş kortikal, 3 olgu kortikal, 5 olguda laküner, 2 olguda kortikal ve laküner enfarktüs vard. 6 olgu arka serebral arter bölgesinde ve 4 olgu ön serebral bölgede idi.

Sonuç: COVID-19 tedavisi sırasında veya tedaviden hemen sonra inmeli hastaların ortaya çıkması, özellikle risk faktörlerinin eşlik ettiği durumlarda virüsün iskemik inmeye yol açtı̆̆ hipotezini düşündürmektedir.
Keywords:

Stroke,

COVID-19,

Computed tomography,

Magnetic resonance imaging,

Cerebrovascular disease

\section{Anahtar Kelimeler:}

Inme,

COVID-19,

Bilgisayarl tomografi,

Manyetik rezonans görüntüleme, Serebrovasküler hastalı

\section{INTRODUCTION}

Coronavirus disease (COVID-19), which began in Wuhan, China in December 2019 and spread rapidly worldwide, is an infectious disease that often causes acute respiratory distress syndrome. However, it has been found to cause numerous diseases of the system in addition to pulmonary diseases (1). It increases daily at the same time as cerebrovascular presentations (2). The relationship between the renin-angiotensin-aldosterone system and the pathogenic potency of SARS-CoV-1 and the pathogenic potency of COVID-19 is very complex. The virus enters host cells by the receptor of the angiotensin 2 conversion enzyme (ACE2) expressed in its various organs. It can cause damage to many organs in COVID-19 with the imbalance between the regulation of ACE2 and the renin-angiotensin system in infected cells $(3,4)$. Vasoconstriction, fluid and salt retention, proinflammatory, pro-coagulation effect, and increased blood pressure occur with enzymatic activation (5). Direct damage to vascular structures of the brain and heart, the tendency to thrombosis due to cytokine storm triggered by inflammation, and hyper viscosity are reported as the main pathogenesis and

Correspondence: Turkan Ikizceli, University of Health Sciences İstanbul Haseki Training and Research Hospital; Adnan Adivar Street, Number: 9, 34130, Fatih, Istanbul, Turkey. E-mail: turkan.ikizceli@sbu.edu.tr

Cite this article as: Gocgun N, Ikizceli I. Imaging findings of ischemic stroke associated with COVID-19. Phnx Med J. 2021;3(1):31-34. 
pathogenesis and predisposing factors of stroke in COVID-19 patients $(6,7)$. However, the lack of information on the genetics behind COVID-19 remains today (8). It has been reported in the literature that infected COVID-19 patients who were previously healthy and had no risk factors for a cerebrovascular disease may be affected for ischemic strokes after COVID-19 infection or during the treatment. Endothelial damages and possible hypoxia may have triggered partial or full vessel embolic events (9). Our knowledge of cerebral vascular events related to COVID-19 today is based on case reports. There are very limited studies in the literature, no comprehensive study.

In this article, we aimed to present the relationship between stroke and COVID-19, stroke types, and imaging findings in COVID-19 with stroke in our pandemic hospital.

\section{MATERIAL AND METHOD}

Study Design: Approval was obtained from the ethics committee of S.B.U. Haseki Education Research Hospital (2021/08). Informed consent was obtained from all patients. Following the declaration of COVID-19 as a global pandemic, our hospital became a pandemic hospital in March 2020. From March to November 2020, COVID-19 diagnosed in patients with stroke $(n=10)$ was included in the study retrospectively. COVID-19 has been diagnosed based on positivity with PCR and clinicallaboratory-radiological findings. Although the PCR test of 2 patients was negative, the imaging findings of the thorax and the laboratory tests were accepted as positive COVID-19 because their results supported COVID-19 infection and the treatment was arranged as of COVID-19 infection. Transient ischemic attacks and patients with ischemia without imaging findings were excluded from the study.

Imaging Techniques: First of all, to eliminate intracranial hemorrhage, a non-contrast brain computed tomography (CT) scan was performed for all patients (PHILIPS Ingenuity, Nederland). The following $\mathrm{CT}$ parameters were used: collimation, $16 \times 1.5 \mathrm{~mm}$; tube current, $150 \mathrm{~mA}$; tube potential, $120 \mathrm{kVp}$; gantry rotation time, $0.5 \mathrm{~s}$; pitch value, 0.93. All images were reconstructed with an image matrix of $512 \times 512$ pixels, an image thickness of $1 \mathrm{~mm}$. Then, magnetic resonance imaging (MRI) and Diffusionweighted MRI (DWI) $(n=10)$ were obtained with a $1.5 \mathrm{~T}$ MR Scanner (GEM flex LG full, USA). The cranial MRI scan included axial, coronal, sagittal non-en-hanced T1weighted images; axial and sagittal T2-weighted images, axial fluid-attenuated inversion recovery (FLAIR) images. The contrast-enhanced examination was added for MR angiography. Our routine MRI stroke protocol included the following sequences acquired in the axial plane: spin-echo DWI $\left(\mathrm{b}=0-1,000 \mathrm{~s} / \mathrm{mm}^{2}\right)$, FLAIR, and gradi-ent-echo T2weighted imaging. The presence of lesions was defined by areas of high signal intensity on DWI. Apparent diffusion coefficient (ADC) maps from each slice were generated from the DWI for each slice. All films were reported by 5 years experienced neuroradiologist. MRI examination could not be performed in 2 patients. Magnetic resonance angiography (MRA) was performed in patients $(n=2)$ whose CT angiography $(n=3)$ was contraindicated.
CT and MRA could not be performed on one of our patients due to high creatine and claustrophobia. Clinical information, stroke risk factors, and case imaging results were recorded. Patients with risk factors are summarized in Table 1.

Table 1: Risk Factors

\begin{tabular}{lcc} 
RISK FACTORS & n & \% \\
\hline Hypertension & 6 & 60 \\
Diabetes mellitus & 5 & 50 \\
Congestive heart failure & 1 & 10 \\
Atrial fibrillation & 1 & 10 \\
Atherosclerotic vascular disease & 1 & 10 \\
None of them & 4 & 30 \\
\hline
\end{tabular}

While categorizing types of strokes, all of our cases are classified as ischemic strokes. Stroke time, size (the largest size was considered mainly), location (cortical, deep lacunar, and white matter), and vascular territory area (anterior cerebral artery territory, posterior cerebral artery territory, and watershed area) were evaluated. Statistical Analysis: The Statistical Package for Social Sciences 15.0 (SPSS, Inc, Chicago, IL, USA) for Windows was used for statistical analyses. Results were presented in number (n) and percent (\%) due to the small number of patients in the study.

\section{RESULTS}

The age range of the 10 patients included in the study was $30-77$, and the mean age was $62 \pm 15.10$ years. All patients had an ischemic stroke. In total, 4 cases (40\%) did not have any risk factors for cerebral vascular disease. 6 cases $(60 \%)$ had risk factors for cerebrovascular disease (hypertension, diabetes mellitus, atrial fibrillation, congestive heart failure, atherosclerosis).

Based on DWI results, seven cases were assessed as acute strokes $(70 \%)$ and three cases as sub-acute strokes (30\%). The size of the stroke was $21.80 \pm 15.83 \mathrm{~mm}$. In 4 cases, the size was extended cortical areas. 3 cases were cortical (Figure 1a,b), 5 cases had a lacunar infarction (Figure 2a-d, 3a,b), 2 cases had cortical and lacunar infarctions. 6 cases were in the posterior cerebral artery territory and 4 cases were in the anterior cerebral artery territory.

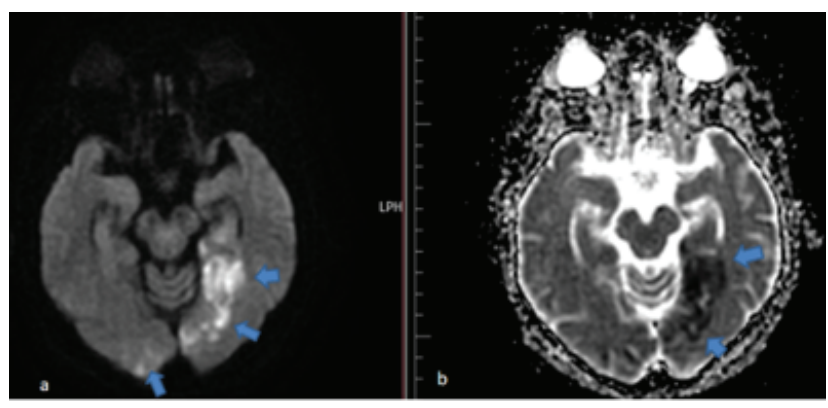

Figure 1: a,b) Diffusion restriction with acute cortical infarction in the PCA territory presenting with sudden vision loss during COVID-19 treatment in a 70-year-old female patient (arrows). 


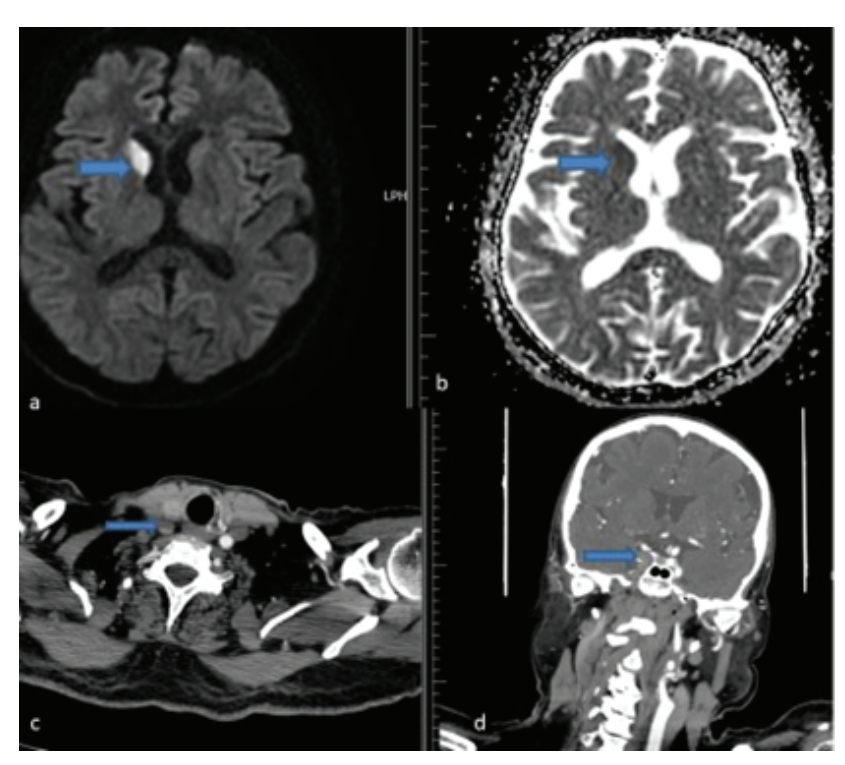

Figure 2: a,b) 64-year-old male patient with COVID-19 without any risk factors for cerebrovascular disease. Acute diffusion restriction in the caudate nucleus head due to right CCA, ICA, MCA, ACA occlusion (arrows) c,d) Acute occlusion in the right CCA and ICA cavernous segment (arrows).

Table 2: Imaging findings according to stroke features, age, and demographic characteristics

\begin{tabular}{|c|c|c|}
\hline & $\mathbf{n}$ & $\%$ \\
\hline Age & \multicolumn{2}{|c|}{$62 \pm 15.10$} \\
\hline \multicolumn{3}{|l|}{ Sex } \\
\hline Male & 7 & 70 \\
\hline Female & 3 & 30 \\
\hline Size & \multicolumn{2}{|c|}{$21.80 \pm 15.83 \mathrm{~mm}$} \\
\hline \multicolumn{3}{|l|}{ Time } \\
\hline Acute & 7 & 70 \\
\hline Subacute & 3 & 30 \\
\hline \multicolumn{3}{|l|}{ Location } \\
\hline & 3 & 30 \\
\hline $\begin{array}{l}\text { Cortical } \\
\text { Lacunar }\end{array}$ & 5 & 50 \\
\hline Cortical+Lacunar & 2 & 20 \\
\hline \multicolumn{3}{|l|}{ Vascular Territory } \\
\hline Anterior & 4 & 40 \\
\hline Posterior & 6 & 60 \\
\hline
\end{tabular}

A watershed stroke had not been seen. Our patients were discharged after they finished treatment for COVID-19 and stroke, and none of them died. Imaging findings, according to stroke types, age, and demographic characteristics are summarized in Table-2.

\section{DISCUSSION}

The virus, which reaches the central system through the neighboring or hematogenous way from the nasal olfactory nerve cells, leads to microthrombus and dissection with direct endothelial damage and causes or facilitates ischemic strokes or cortical small vessel occlusions (5).

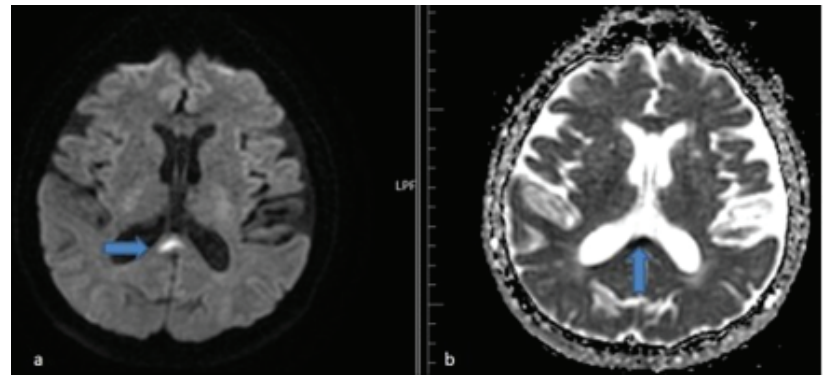

Figure 3: a,b) A 58-year-old male patient with acute lacunar infarction (arrows) with diffusion restriction was observed on diffusion imaging.

In the literature, this mechanism is highlighted in stroke cases associated with COVID-19. The stenosis of large vessels and cardiogenic causes are implicated in the etiologies of cortical infarct (10). In our study, 3 patients with cortical infarction had cardiogenic risk factors such as pacemaker and atrial fibrillation, while not have large vessel stenosis. However, the fact that our cases are receiving corona treatment or after a few days of COVID-19 suggests the existence of an interaction between the COVID-19 virus and cardiac-related strokes. In the study conducted by the global COVID-19 stroke center in 174 patients with COVID-positive stroke, they mentioned that both direct vascular injury, various reactions caused by inflammatory agents, and infections may cause a stroke by triggering cardiac arrhythmia $(11,12)$.

One of our two patients with both cortical and lacunar stroke had hemodynamically significant stenosis in Basillary Artery, and it was a possible source of thrombus for Posterior Cerebral Artery occlusion. The other patient had an ischemic stroke while is receiving treatment for COVID-19 pneumonia. In his angiography, ipsilateral Internal Carotid Artery (ICA) was occluded, there was no plaque or stenosis in vascular structures except wall calcifications, but there were chronic ischemic gliotic signals in the left centrum semiovale on FLAIR sequence, which may indicate the presence of ICA hemodynamically significant stenosis. As a known mechanism in the literature, it is stated that infection may accelerate atherosclerosis, occlusion, and cause stroke (13). COVID-19 virus is reported to reach the central system, which is the cause of lacunar infarction. In our case series, most of our cases were types of small-vessel occlusion. We detected less large vessel occlusion. However, risk factors for stroke were also present. The lacunar infarct is a type of stroke that means a maximum diameter of $20 \mathrm{~mm}$, localized in the basal ganglia, brainstem, deep white matter, and occurs due to the occlusion of short perforating vessels. It is mainly associated with uncontrolled hypertension and diabetes mellitus (14). In our study, 7 patients had lacunar infarction. Only one of our patients has been diagnosed with hypertension. In the study of Baudin et al. 89 cases with lacunar infarction with COVID-19 positive were examined and stroke was associated with the microangiopathic effect caused by the infection (15). 
In the study by Ntaios et al. lacunar infarction was reported in a total of $17.8 \%$ (11). In our study, the rate of total lacunar infarction was $70 \%$, and the rate was very high compared to the literature. One reason is the relatively high rate associated with a low number of cases. Although common carotid artery and ICA were total thrombosed in one of the patients in the lacunar infarct group, less diffusion restriction than we expected was observed in the acute period on diffusion imaging. This case referred to interventional radiology for thrombectomy but thrombectomy was not successful. In the subacute period, the diffusion restriction of this patient progressed to the entire Middle Cerebral Artery. It has been reported in the literature that large vessel occlusion and strokes associated with COVID-19 may even be one of the clinical presentation forms $(16,17)$. Another reason; according to Hernandez-Fernandez et al.'s research, cases with lacunar infarction present less to hospitals due to the pandemic, and therefore it is estimated that the actual number is higher than we recorded (18-20).

Limitations; the small number of cases is the biggest limitation of the study. Besides the small number of cases, there was no homogeneous distribution. There were no previous imaging findings of the cases and angiography could not be performed in all cases. The RT-PCR test of 2 cases was negative, they were diagnosed with COVID-19 pneumonia according to thorax findings. There may be a case who came to the hospital due to stroke and was coincidentally diagnosed with COVID-19. As a result, the presentation of patients with stroke during corona disease therapy or after therapy might be considered the hypothesis that the virus led to a stroke, especially in cases accompanied by risk factors. Largescale multicenter studies will be more informative in this regard.

Conflict of Interest: No conflict of interest was declared by the authors.

\section{REFERENCES}

1. Ozkan S, Tutar O, Akdeniz YS, Cakmak F, Ipekci A, Biberoglu S. Chest Computed Tomography Findings of Eight Patients With Covid-19 Diagnosis: Case Series. Acta Biomed. 2021 Jan 19;91(4):e2020136.

2. Saggese CE, Del Bianco C, Di Ruzza MR, Magarelli M. COVID-19 and Stroke: Casual or Causal Role? Cerebrovasc Dis 2020;49:341-344.

3. Hamming I, Timens W, Bulthius MLC, Lely AT, Navis GJ, van Goor H. Tissue distribution of ACE2 protein, the functional receptor for SARS coronavirus. A first step in understanding SARS pathogenesis. J Pathol. 2004; 203 (2): 631-637.

4. Ni W, Yang X, Yang D, et al. Role of angiotensin-converting enzyme 2 (ACE2) in COVID-19. Crit Care. 2020;24(1):422.

5. Hess DC, Eldahshan W, Rutkowski E. COVID-19-Related Stroke. Translational Stroke Research. 2020 Jun; 11 (3): 322-325.

6. Valderrama EV, Humbert K, Lord, Frontera J, Yaghi S. Severe Acute Respiratory Syndrome Coronavirus2 Infection and Ischemic Stroke. Stroke. 2020; 51:124 -127.

7. Karcığlu Ö. Coronavirüs Nedir, Nasıl Korunabiliriz? Phnx Med J. 2020; 2(1): 66-71.

8. Nain Z, Rana HK, Liò P, Islam SMS, Summers MA, Moni MA. Pathogenetic profiling of COVID-19 and SARS-like viruses. Brief Bioinform 2020, (Epub ahead of print).

9. Rascón-Ramírez FJ, Carrascosa-Granada ÁM, Vargas-Jiménez AC, Ferrández-Pujante B, Ortuño-Andériz F. Supra and infratentorial massive strokes in previously healthy young patients with SARS-CoV-2. Neurocirugia (Astur). 2020;doi:10.1016/j.neucir.2020.08.001 (Epub ahead of print)

10. Amarenco P, Bogousslavsky J, Caplan LR, Donnan GA, Hennerici MG. Classification of stroke subtypes. Cerebrovasc Dis. $2009 ; 27$ (5): 493-501.

11. Ntaios G, Michel P, Georgiopoulos G, et al. Characteristics and Outcomes in Patients With COVID-19 and Acute Ischemic Stroke: The Global COVID-19 Stroke Registry. Stroke. 2020 Sep;51(9):e254-e258.

12. Miller EC, Elkind MS. Infection and stroke: an update on recent progress. Curr Neurol Neurosci Rep. 2016; 16: 2.

13. Nagel M, Mahalingam R, Cohrs RJ, Gilden D. Virus vasculopathy and stroke: an under-recognized cause and treatment target. Infect Disord Drug Targets. 2010; 10 (2): 105--11.

14. Wardlaw JM. What causes lacunar stroke? J Neurol Neurosurg Psychiatry. 2005; 76: 617-619.

15. Baudin PN, Caamaño IR, Rubio-Maicas C et al. COVID-19 and Ischemic Stroke: Clinical and Neuroimaging Findings. J Neuroimaging 2020, doi: 10.1111/jon.12790. (Epub ahead of print).

16. Oxley TJ, Mocco J, Majidi S, et al. large-vessel stroke as a presenting feature of COVID-19 in the young. N Engl J Med. 2020; 382 : e60.

17. Beyrouti R, Adams ME, Benjamin L, et al. Characteristics of ischaemic stroke associated with COVID-19. J Neurol Neurosurg Psychiatry. 2020 Aug;91(8):889-891.

18. Starkey J, Kobayashi N, Numaguchi Y, Moritani J. Cytotoxic Lesions of the Corpus Callosum That Show Restricted Diffusion: Mechanisms, Causes, and Manifestations1. RadioGraphics 2017; 37:562-576.

Hernández-Fernández F, Sandoval Valencia H, Barbella-Aponte RA, et al. Cerebrovascular disease in patients with COVID-19: neuroimaging, histological and clinical description. Brain. 2020 Oct 1;143(10):3089-3103.

20. Aydın T, Kesiktaş FN, Çorum M. Analysis of Stroke Patients Requiring Re-hospitalisation for Rehabilitation. Med Bull Haseki 2020;58:422-427. 